\title{
Article \\ Natural Radioactivity, Radiological Hazard and Petrographical Studies on Aswan Granites Used as Building Materials in Egypt
}

\author{
Nasser M. Moghazy ${ }^{1}$, Amira M. El-Tohamy ${ }^{1}$, Mona M. Fawzy ${ }^{1}$, Hamdy A. Awad ${ }^{2,3}$, Hesham M. H. Zakaly ${ }^{4,5, *(D,}$ \\ Shams A. M. Issa ${ }^{4,6}$ and Antoaneta Ene ${ }^{7, * \text { (D) }}$ \\ 1 Nuclear Materials Authority, P.O. 530 Maadi, Cairo 11381, Egypt; nassmoghazy@yahoo.com (N.M.M.); \\ amira_eltohamy2011@yahoo.com (A.M.E.-T.); mm1_fawzy@yahoo.com (M.M.F.) \\ 2 Institute of Earth Sciences, Southern Federal University, Zorge St. 40, 344103 Rostov-on-Don, Russia; \\ havad@sfedu.ru \\ 3 Geology Department, Faculty of Science, Al-Azhar University, Assuit Branch, Assuit 71524, Egypt \\ 4 Physics Department, Faculty of Science, Al-Azhar University, Assuit 71524, Egypt; shams_issa@yahoo.com \\ 5 Institute of Physics and Technology, Ural Federal University, 620002 Yekaterinburg, Russia \\ 6 Department of Physics, Faculty of Science, University of Tabuk, Tabuk 71451, Saudi Arabia \\ 7 INPOLDE Research Center, Faculty of Sciences and Environment, Department of Chemistry, \\ Physics and Environment, Dunarea de Jos University of Galati, 47 Domneasca Street, 800008 Galati, Romania \\ * Correspondence: h.m.zakaly@azhar.edu.eg (H.M.H.Z.); aene@ugal.ro (A.E.)
}

check for updates

Citation: Moghazy, N.M.; El-Tohamy, A.M.; Fawzy, M.M.; Awad, H.A.; Zakaly, H.M.H.; Issa, S.A.M.; Ene, A. Natural Radioactivity, Radiological Hazard and Petrographical Studies on Aswan Granites Used as Building Materials in Egypt. Appl. Sci. 2021, 11, 6471. https://doi.org/10.3390/ app11146471

Academic Editor: Eduardo

Ferreira da Silva

Received: 13 June 2021

Accepted: 11 July 2021

Published: 13 July 2021

Publisher's Note: MDPI stays neutral with regard to jurisdictional claims in published maps and institutional affiliations.

Copyright: (c) 2021 by the authors. Licensee MDPI, Basel, Switzerland. This article is an open access article distributed under the terms and conditions of the Creative Commons Attribution (CC BY) license (https:// creativecommons.org/licenses/by/ $4.0 /)$.

\begin{abstract}
The present study was carried out on commercial types of Aswan granite used as building and decorative materials. Nearly 29 granitic rocks samples from 11 classes (black Aswan, red Aswan, dark Rosa, light Rosa, yellow Verdi, grey Shirka, Gandolla, Forsan, red Nefertiti, Royal, and white Halayeb) were collected from three stations near Aswan city for petrographical description and assessment of natural radioactivity. The petrographical study of granites was conducted by polarizedlight microscope in order to determine their mineralogical composition and investigate their texture; the activity of the natural radionuclides ${ }^{238} \mathrm{U}, \mathrm{Ra}^{226},{ }^{232} \mathrm{Th}$, and ${ }^{40} \mathrm{~K}$ was measured by gamma-ray spectrometry with a $\mathrm{NaI}(\mathrm{Tl})$ detector. The average values of the activities, $52.2 \mathrm{~Bq} \mathrm{~kg}^{-1}, 57.8 \mathrm{~Bq} \mathrm{~kg}^{-1}$, 31.2 $\mathrm{Bq} \mathrm{kg}^{-1}$, and 1055.7 Bq kg ${ }^{-1}$ of U-238, Th-232, Ra-226, and $\mathrm{K}-40$, respectively, were higher than that the world average values of $35 \mathrm{~Bq} \mathrm{~kg}^{-1}, 30 \mathrm{~Bq} \mathrm{~kg}^{-1}$ and $400 \mathrm{~Bq} \mathrm{~kg}{ }^{-1}$ for ${ }^{226} \mathrm{Ra}$, ${ }^{232} \mathrm{Th}$, and ${ }^{40} \mathrm{~K}$, respectively, according to the recommended levels from UNSCEAR reports. The minimum and maximum values obtained were compared with the value ranges from other locations in the Eastern Desert, highlighting the fact that that the maximum values obtained in this work are higher than those in other areas. According to the radiological hazards indices results, most samples lie in the permissible level ranges, suggesting their favorability for use as building materials. In contrast to that, some samples have some environmental parameters higher than the international levels, indicating their unsuitability as building materials.
\end{abstract}

Keywords: Aswan granites; ornamental stones; radioactive content

\section{Introduction}

Human beings have always been exposed to ionizing radiations of natural origin, namely, terrestrial and extraterrestrial radiation [1,2]. Radiation of extraterrestrial origin is from high energy cosmic ray particles, and at sea level, it is about $30 \mathrm{nGyh}^{-1}$, while that of terrestrial origin is due to the presence of naturally occurring radionuclides, mainly potassium $\left({ }^{40} \mathrm{~K}\right)$, rubidium, and the radionuclides in the decay chains of thorium $\left({ }^{232} \mathrm{Th}\right)$ and uranium $\left({ }^{238} \mathrm{U}\right)$ [3]. Monitoring natural radioactivity in the environment and building materials is very important for the estimation of radiation doses and the radiological protection of the population.

The term "granite" is used world-wide to describe granitic rocks studied in igneous petrology, and many other igneous rock types used as building materials in the dimension 
stone market. In recent years, granites used as building materials have been very popular; the global amount of granite production is comparable to that of marble [4]. Due to their durability and prestigious appearance, granitic rocks are widely used as building and decorative materials in buildings, bridges, monuments, pavement sidewalks, and many other exterior projects [5,6]. Indoor, polished granite slabs and tiles are used in countertops, tile floors, stair treads, and many other design elements. There are some mechanical and physical tests that were carried out on the various forms of Aswan granite [7]. An example is the use of these granites by the ancient Egyptians, due to their good properties for the construction of the pyramids, pharaonic statues and other Egyptian monuments that were made of these granites.

Generally, granites exhibit an enhanced concentration of $U$ and Th, compared to the very low abundance of these elements observed in the Earth's crust. The activity concentrations of ${ }^{226} \mathrm{Ra},{ }^{232} \mathrm{Th}$, and ${ }^{40} \mathrm{~K}$ of granitic rocks in the Um Taghir area were found to be normal [8], while the granites of the El-Missikat area-considered uraniferous rocks related to high concentrations of uranium (U), thorium (Th), and potassium (K)—contained high concentrations of radioactive elements [9].

Aswan granitic rocks occupy a region in southern Egypt and cover the central part of the area near Aswan city within latitudes $24^{\circ} 5^{\prime}, 18^{\circ} 5^{\prime} \mathrm{N}$ and longitudes $32^{\circ} 53^{\prime}, 26^{\circ} 07^{\prime} \mathrm{E}$. Aswan granite was the third most important stone used in the Egyptian civilization, following sandstone and limestone. It was used for vases, statues, sarcophagi, and buildings, commencing from at least the Early Dynastic Period [10].

In this study, Aswan granitic rocks are represented by light grey medium-grained granites, red coarse-grained granites, and fine-grained granites. The latter one is the most widely-used type. An increase in the concentration of both $U$ and Th might be due to the presence of some additional minerals, such as orthite or allanite, monazite, zircon, apatite, and sphene, which are usually concentrated in granitic rocks [11].

The objective of this research is a survey and measurements of the natural terrestrial radionuclides, such as ${ }^{40} \mathrm{~K},{ }^{238} \mathrm{U},{ }^{226} \mathrm{Ra}$, and ${ }^{232} \mathrm{Th}$, in conjunction with the mineralogical contents of Aswan granites that are used as building materials in order to understand the relationship between natural radioactivity and the content of radioactive minerals.

\section{Geological Setting}

The Ancient Egyptians used the famous Aswan monumental red granite for manufacturing obelisks and coffins for their kings. Based on previous mapping [12], four types of post-collisional, largely undeformed granites are distinguished in the Aswan area: (1) a coarse-grained, porphyritic, fairly mafic, mainly tonalitic "granodiorite", which we refer to as Aswan Tonalite; (2) the famous, coarse-grained, pink to red, porphyritic Monumental Granite with rapakivi textures in places; (3) the fine-grained, mostly pink Saluja-Sehel Granite; and (4) the so-called High-Dam Granite, which is a coarse-grained, mostly nonporphyritic biotite granite. The regional distribution of these granitoids indicates that Aswan Tonalite is the oldest intrusion, followed by the intrusion of Monumental Granite and fine-grained Saluja-Sehel Granite. These three form the composite pluton, south of Aswan City. High-Dam Granite is considered the youngest intrusion. It forms, by far, the largest body and is located further south, near the so-called "High-Dam" of the Nile reservoir. Several authors have suggested that all four plutonic units are comagmatic, with the magmas derived from the same or a similar source but having undergone varying degrees of magmatic differentiation during ascent [12-14].

In the present study, eleven popular types of Aswan commercial granitic samples used as ornamental stones were investigated. These types are polished granite tiles ready for use (plate 1) collected from three zones (Figure 1a-c). The selected polished samples were collected over a wide area around Aswan city (Figure 1a), east of Aswan city (Figure $1 \mathrm{~b})$, and south of Aswan city (Figure 1c). Generally, the commercial ornamental granite samples intrude on the older country rocks (metasediments and metavolcanics in Figure 1a, older granite in Figure 1b, and metasediments in Figure 1c). The contacts are usually sharp, 
intrusive ones. These granites are conformably overlain by the Nubian Sandstones in many locations. The selected samples are represented by a wide range of grey medium-grained granites, red coarse-grained granites, and fine-grained granites.
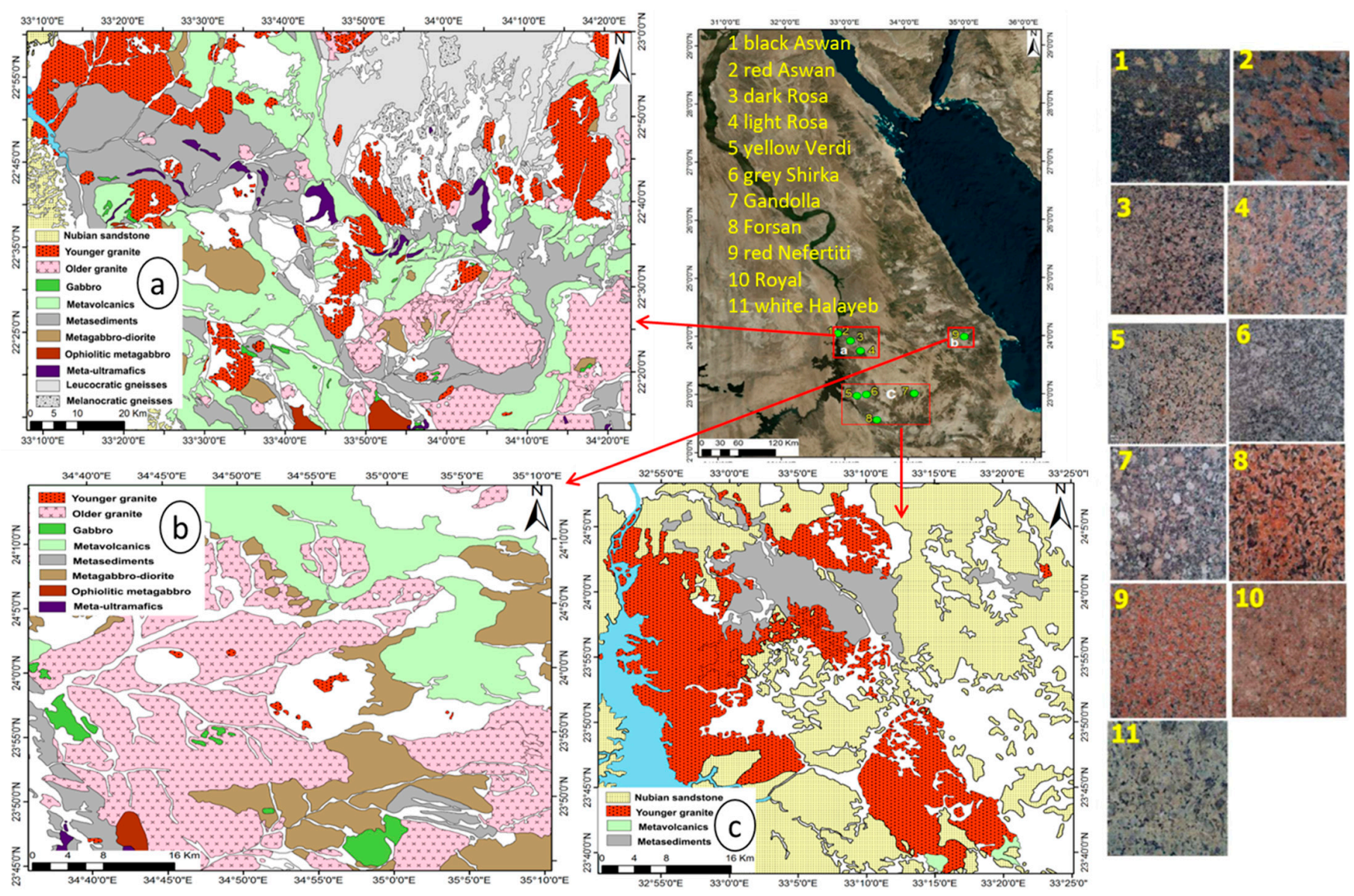

Figure 1. Granite sampling locations over a wide area (a) around Aswan city, (b) east of Aswan city, and (c) south of Aswan city with the appearance of Aswan granites: 1-black Aswan, 2-red Aswan, 3-dark Rosa, 4-light Rosa, 5-yellow Verdi, 6-grey Shirka, 7-Gandolla, 8-Forsan, 9-red Nefertiti, 10-Royal, 11-white Halayeb.

The medium grained granites form a number of sheet-like masses graded into the coarse-grained granite varieties. They range in composition from quartz diorites to granodiorites; the most abundant variety is the grey-colored granodiorite spotted with white and pinkish feldspar porphyroblasts, which sometimes show linear arrangement (Figure 1, slap 6 grey Shirka). Gneissose granodiorite is often developed near contact with the red coarse-grained granite. The granodiorites enclose big, elongated xenoliths from the surrounding older metamorphites. The coarse-grained granites (Figure 1, slap 2 red Aswan) are widely distributed in the area (Figure 1a) and form most of the hills between Aswan and Shellal and underlies the Nubia Sandstone in many localities. They are cut by sheets and dykes of fine-grained granite and pegmatites. This granite is normally pinkish in color with abundant pink feldspar porphyroblasts of up to $4 \mathrm{~cm}$ in length. The fine-grained variety forms sheets, dykes, and irregular elongated masses cutting mainly the coarsegrained granite. These granites are homogeneous, non-porphyritic, fine-grained, and show pinkish to greyish colors (Figure 1, slap 3 and 4, dark and light Rosa). Both the coarseand fine-grained Aswan granites comprise monzogranite and syenogranite varieties of metaluminous and calc-alkaline affinities [15].

Aswan granitic rocks occupy a unique position between the Precambrian exposures of the South Eastern and South Western Deserts of Egypt [16]. To the east, basinal facies of metasedimentary and metavolcanic rocks, together with batholithic older granites and 
younger granite plutons, form extensive outcrops, which represent the southern extension of the Pan-African Precambrian belt of the Eastern Desert. An evolutionary model of Island arc formation and obduction-accretion tectonics is envisaged for this area. The rocks of the south Western Desert were characterized by three episodes of deformation and related metamorphism and anatexis until the final cratonization during the late Pan-African event was completed. As a consequence of the convergence of East and West Gondwana and the closure of the Mozambique ocean, this juvenile crust accreted against the Saharan Metacraton by the end of the Proterozoic [17] and was intruded by a large number of granitoids [18].

\section{Materials and Methods}

About twenty-nine samples were collected from the most popular eleven commercial types of Aswan granite, already used as building and ornamental materials to be studied for their natural radioactivity. The samples were labeled as B1-B5 (Black Aswan), G1-G3 (Gray Shirka), L1-L2 (Light Rosa), D1-D2 (Dark Rosa), R1-R3 (Royal), Gn1-Gn3 (Gandolla), R1-R3 (Red Aswan), W1-W3 (White Halayeb), Y1-Y3 (Yellow Verdi), RN (Red Nefertiti) and $\mathrm{F}$ (Farsan).

All the investigations were carried out at the laboratories of the Egyptian Nuclear Materials Authority (NMA). Thin sections of the samples were prepared and analyzed by polarized-light microscope in order to determine their mineralogical composition and investigate their texture. Then, the samples were subjected to comminution processes, including crushing and grinding. The crushing process was carried out using a jaw crusher to prepare a feed about $-3 \mathrm{~mm}$ for the grinding process. Then, the grinding process took place using a Denver pilot rod mill to reduce the size to $100 \%$, passing $0.5 \mathrm{~mm}$.

The comminuted samples were subjected to radiometric analysis using gamma spectrometry after drying at $80^{\circ} \mathrm{C}$ to remove moisture, which otherwise would result in selfabsorption of the radionuclides during the radio assay. About $300 \mathrm{~g}$ of dried comminuted samples were packed in labeled cylindrical plastic containers of a uniform base diameter of $9.5 \mathrm{~cm}$ and $3 \mathrm{~cm}$ in height. The plastic containers were tightly covered, sealed and left for 30 days prior to counting for the attainment of the secular equilibrium between ${ }^{238} \mathrm{U}$ and ${ }^{232} \mathrm{Th}$ and their respective progenies $[19,20]$. The instrument used in the determination of the four radioactive elements consists of a gamma spectrometric chain with a $76 \times 76 \mathrm{~mm}$ Bicron scintillation detector $\mathrm{NaI}(\mathrm{Tl})$, hermetically sealed with the photomultiplier tube in aluminum housing. The tube is protected by a copper cylinder of $0.6 \mathrm{~cm}$ thickness against induced $\mathrm{X}$-rays and a chamber of lead bricks against environmental radiation.

Uranium, thorium, radium and potassium were measured by using four energy regions, representing Th-234, Pb-212, Pb-214 and K-40 gamma emitters at $93 \mathrm{keV}, 239 \mathrm{keV}$, $352 \mathrm{keV}$, and $1460 \mathrm{keV}$, respectively. The measuring values of $\mathrm{U}$, Th and Ra in parts per million (ppm), as well as of $\mathrm{K}$ in percent values (\%), were converted to activity concentrations as Becquerel per kilogram $\left(\mathrm{Bq} \mathrm{kg}^{-1}\right)$, using the conversion factors given by the Polish Central Laboratory for Radiological Protection [21,22].

\section{Results and Discussion}

\subsection{Sample Petrographic Description}

The massif of the Aswan region consists of granitic rocks of the Precambrian age, the earlier phases of which are more mafic, coarse-grained, and sometimes show porphyritic and rapakivi textures. The K-feldspar megacrysts show intensive perthitization of an exolution origin and occur in more than one generation, sometimes replacing each other. The K-feldspar includes oriented plagioclase crystals that lie parallel to the re-entrant angles at the Carlsbad twinning planes of the K-feldspar megacrysts.

The plagioclase megacrysts also contain oriented biotite, magnetite, and apatite inclusions that are concentrated in the cores and between the cores and their outer rims. Occasionally, these include crystals lying parallel to the re-entrant angles at the Carlsbad twinning planes of the plagioclase megacrysts. These features suggest crystallization of the 
K-feldspar and plagioclase megacrysts from silicate melts and lend some support to the magmatic hypothesis of the Aswan batholith.

Aswan granite is composed mainly of alkali-feldspars, plagioclase, quartz, biotite, and hornblende. Zircon, allanite, epidote, titanite, and opaques are the main accessory minerals. The studied granites are generally light grey with a reddish tone. The rocks are equigranular and exhibit a phaneritic texture. The main constituents are quartz (20-35\%), K-feldspar (up to $50 \%$ ), plagioclase (10-25\%) and subordinate biotite \pm amphibole (5-16\%). Quartz is observed in the rocks as medium- to coarse-grained, occurring as anhedral crystals. Minute quartz crystals occupy the interstitial spaces between feldspars.

The potash feldspars are the main constituents and represented by perthite, microcline perthite, orthoclase perthite, and microcline. Perthite occurs as subhedral crystals and has both albite and pericline twinning, which form a known tartan pattern (Figure 2a). Some crystals of perthite include the second phase of biotite (Figure 2b). Microcline perthite occurs as an anhedral crystal associating plagioclase (Figure 2c) and sometimes includes crystals of zircon (Figure 2d). Orthoclase perthite occurs as euhedral to subhedral crystals showing simple twinning; sometimes, some crystals of orthoclase perthite are found enclosing the second phase of albite (Figure 2e). Exsolution textures are commonly represented by perthite and equilibrium quartz-feldspar intergrowth (i.e., myrmekite).
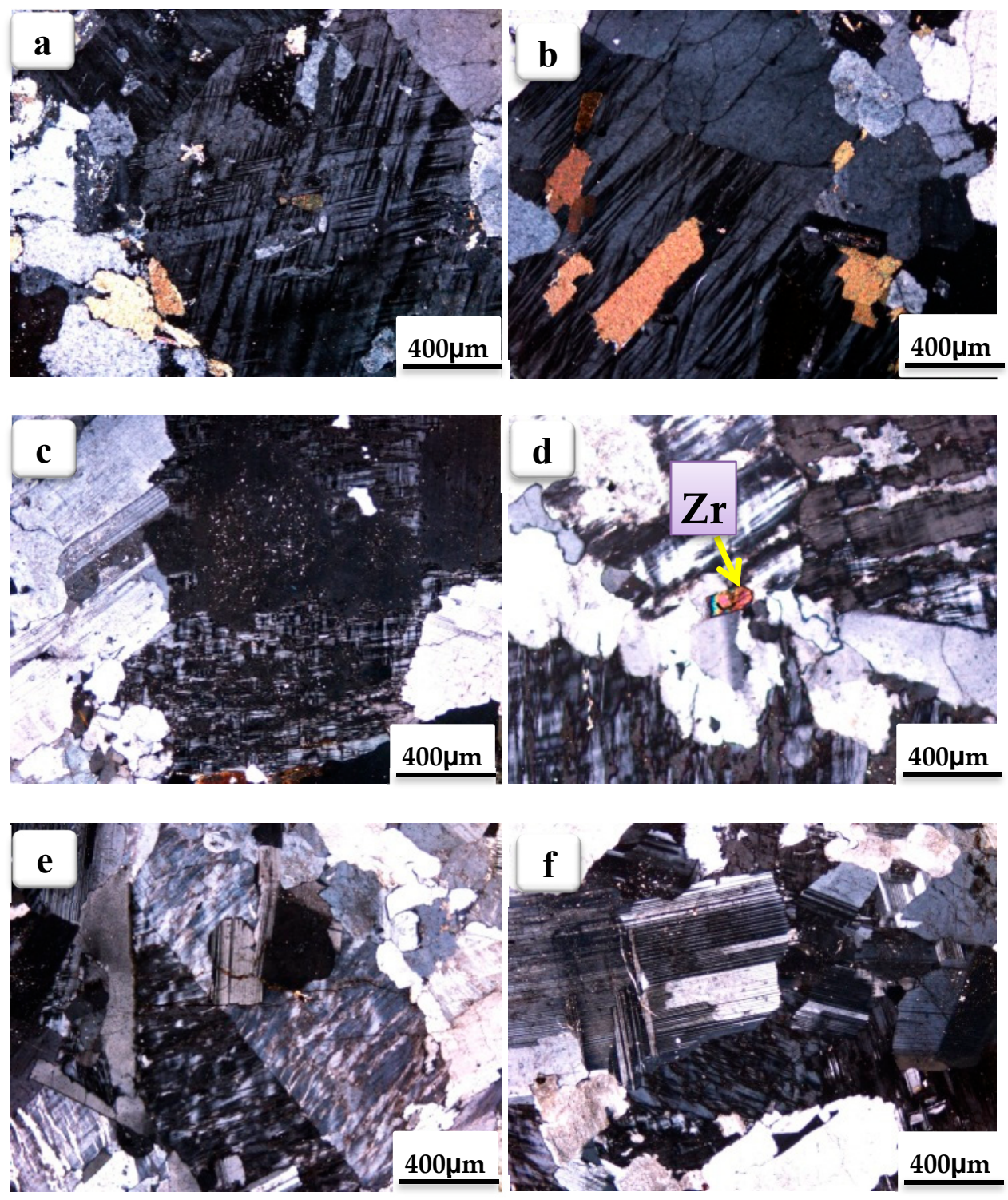

Figure 2. Cont. 

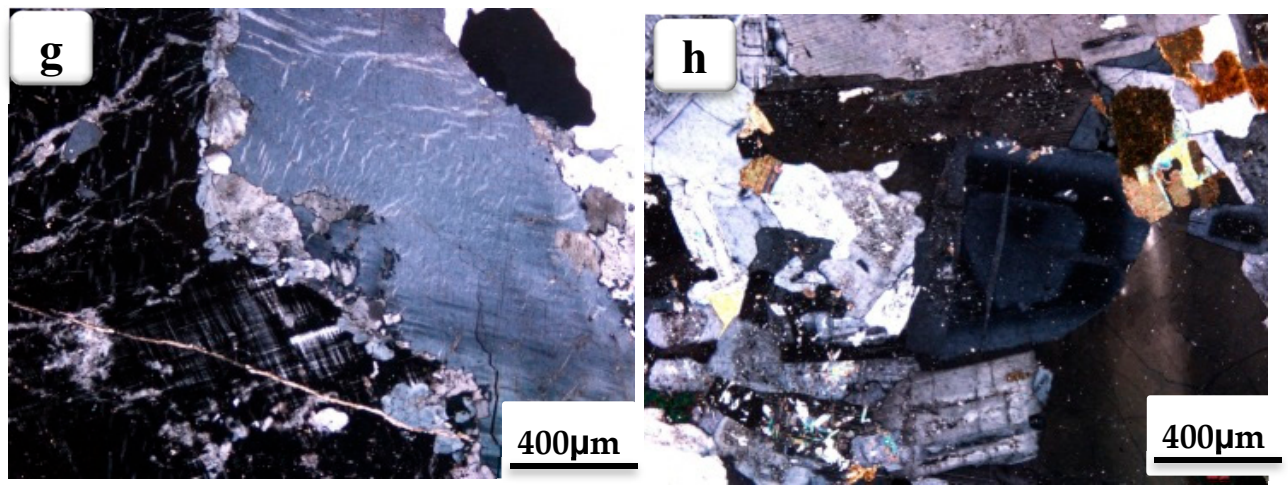

Figure 2. Photomicrographs for Aswan granite showing: (a) Subhedral crystal of perthite of tartan type, CN. (b) Second phase of biotite in perthite, CN. (c) Anhedral crystal of microcline perthite associating plagioclase, $\mathrm{CN}$. (d) Well-formed crystal of zircon associating quartz and microcline perthite, CN. (e) Subhedral crystal of orthoclase perthite enclosing second phase of albite, CN. (f) Euhedral crystal of plagioclase with lamellar twining associating perthite, CN. (g) Anhedral crystals of plagioclase with vermicular of quartz (myrmikitic) on the border of string perthite, $\mathrm{CN}$. (h) Zoned crystal of plagioclase associating albitic plagioclase, quartz and biotite, CN.

Plagioclase is represented by subhedral to euhedral prismatic crystals of variable sizes with distinct lamellar twinning (Figure 2f). Myrmekite texture is developed at the margins of plagioclase and microcline (Figure $2 \mathrm{~g}$ ). Some plagioclase crystals are oscillatory zoned (Figure 2h). It is coarse to very coarse grains which are digested and mantled by perthite (Figure 3a), referring to the mixing magma. Epidotization and muscovitization are the main alteration product of plagioclase (Figure 3b,c). The plagioclase exsolution lamellae are large enough to exhibit the characteristic polysynthetic twinning pattern (parallel stripes). In contrast, the K-feldspar host displays splendid "tartan" or "cross-hatched" twinning.
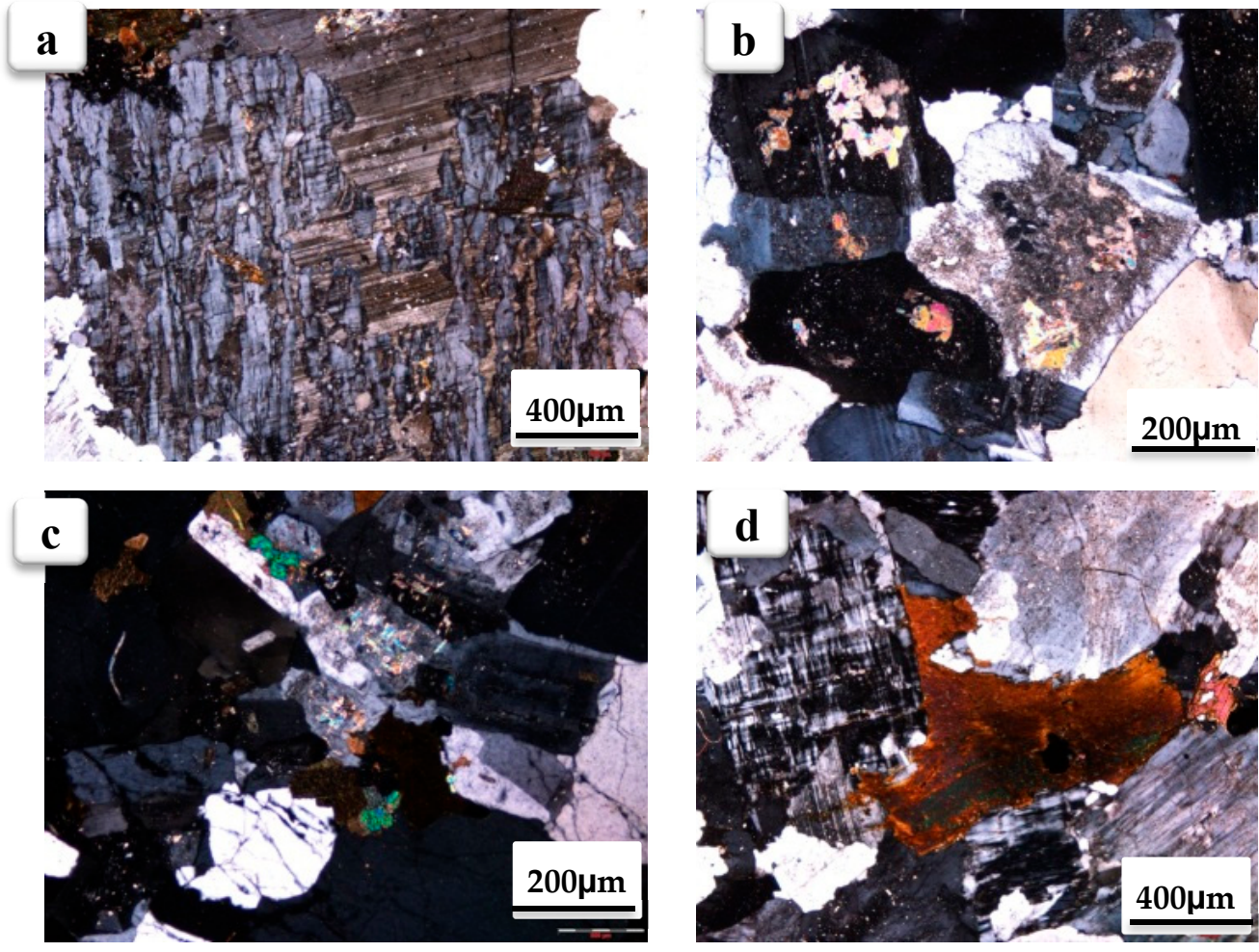

Figure 3. Cont. 

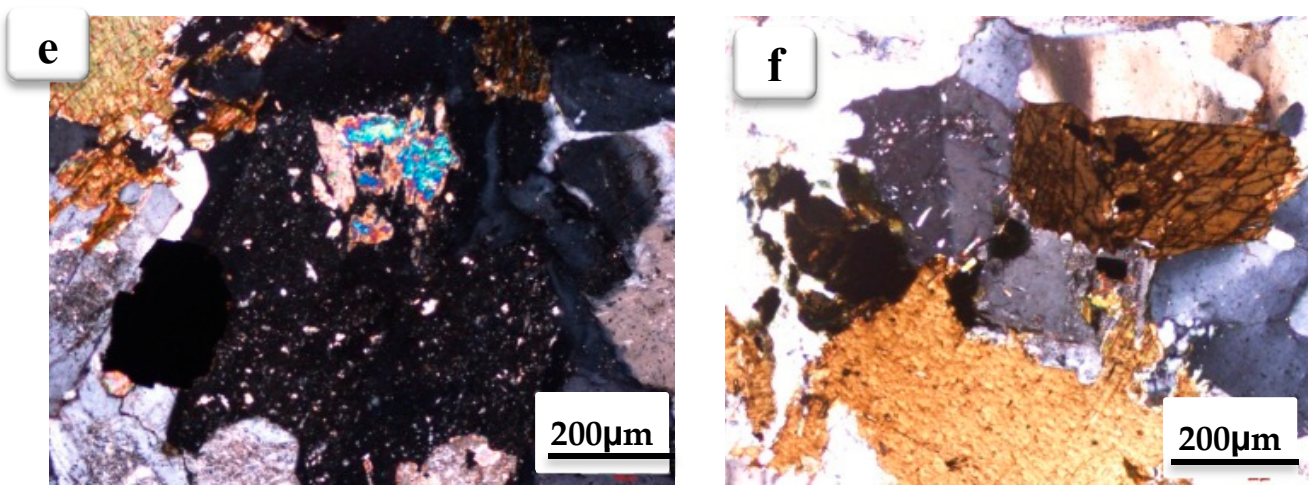

Figure 3. Photomicrographs for Aswan granite showing: (a) Plagioclase corroded by perthite, $\mathrm{CN}$; (b) epidotization and muscovitization of plagioclase, $\mathrm{CN}$; (c) muscovitization of plagioclase, $\mathrm{CN}$; (d) anhedral flake of ferribiotite associating antiperthite, $\mathrm{CN}$; (e) secondary muscovite after plagioclase (muscovitization), $\mathrm{CN}$; (f) basal section of hornblende with two-sets cleavage associating plagioclase, $\mathrm{CN}$.

The mafics are represented by biotite, muscovite and hornblende. Biotite is brown in color and occurs as anhedral crystals of ferribiotite associating antiperthite (Figure $3 \mathrm{~d}$ ). The second phase of biotite occurs in the perthite of the tartan type (see Figure 3b). Muscovite occurs as a secondary mineral after plagioclase (muscovitization) (Figure 3e). Hornblende occurs as elongated prismatic crystals in the basal section monoclinic, dark green to dark brown in color, strongly pleochroic, from dark green to yellow (Figure 3f).

Zircon occurs as well-formed crystals and exhibits its characteristic of interference colors (Figure 4a). Deformed crystals are enclosed in biotite and feldspars (Figure 4b). Allanite occurs as well-formed metamict crystals characterized by zoning and masked interference colors (Figure 4c). Titanite occurs as well-formed crystals with sphenoidal forms (Figure 4d,e). Epidote occurs as secondary oval crystals exhibiting their characteristic interference colors and coexists with ferribiotite (Figure 4f).
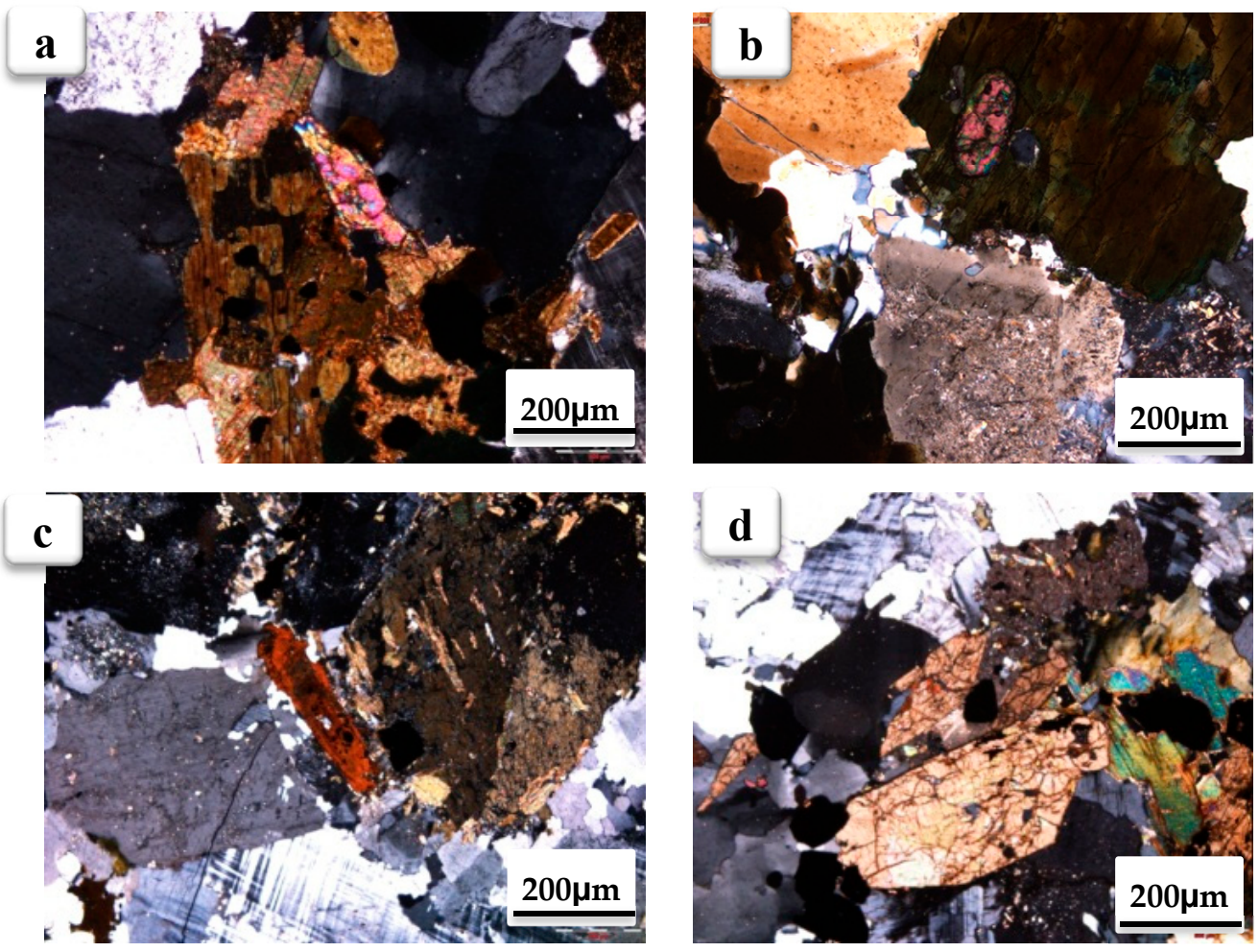

Figure 4. Cont. 

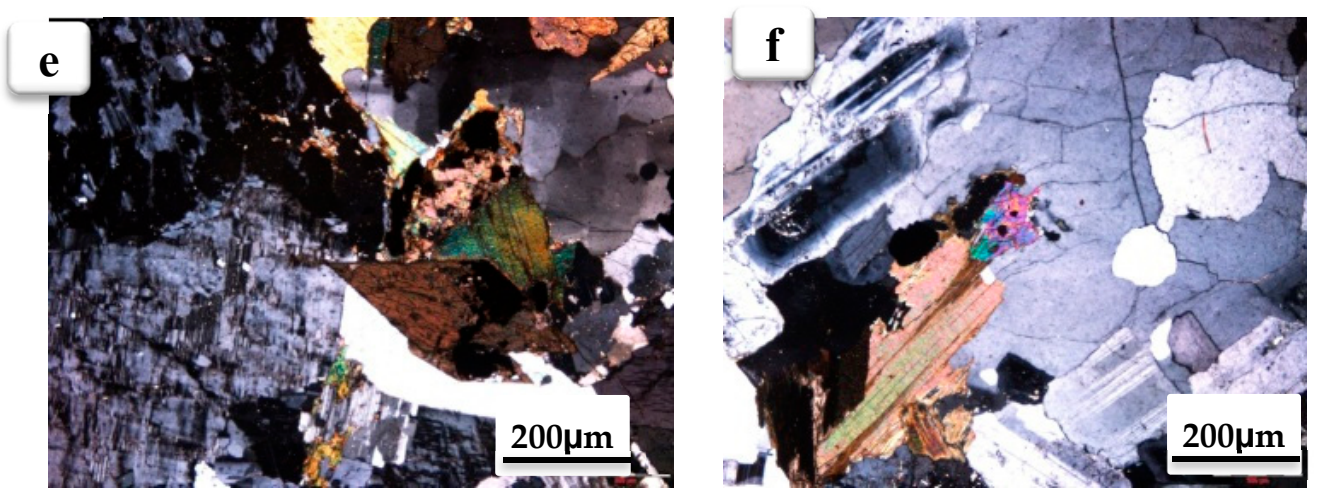

Figure 4. Photomicrographs for Aswan granite showing: (a) Deformed crystal of zircon associating biotite, hornblende and quartz, CN; (b) euhedral crystal of zircon in BI, CN; (c) zoned crystal of metamict allanite associating perthite, plagioclase, and opaque, $\mathrm{CN}$; (d) well-formed crystals of titanite with prismatic and sphenoidal forms (sphene), $\mathrm{CN}$; (e) well-formed crystals of titanite with sphenoidal forms (sphene) associating antiperthite, $\mathrm{CN}$; (f) secondary epidote associating plagioclase and quartz, CN.

\subsection{Analysis of Radionuclides}

Gamma-ray spectrometry is a powerful, non-destructive analytical tool for the qualitative and quantitative determination of gamma emitters [20]. The specific activity (activity per unit mass) is the number of atomic decays per unit time per unit mass. It is used to describe the radionuclide contents of rocks and building materials [23] and is expressed in becquerel per kilogram $\left(\mathrm{Bq} \mathrm{kg}^{-1}\right)$, where $1 \% \mathrm{~K}=313 \mathrm{~Bq} \mathrm{~kg}^{-1}, 1 \mathrm{ppm} \mathrm{U}=12.35 \mathrm{~Bq} \mathrm{~kg}^{-1}$ and $1 \mathrm{ppm}$ Th $=4.06 \mathrm{~Bq} \mathrm{~kg}^{-1}$ as recommended by [24]. The calculated activity values of ${ }^{238} \mathrm{U},{ }^{226} \mathrm{Ra},{ }^{232} \mathrm{Th}$ and ${ }^{40} \mathrm{~K}$ radionuclides, expressed in $\mathrm{Bq} \mathrm{kg}^{-1}$, are given in Table 1 for the twenty-nine different samples of Aswan granites investigated in this work.

The average values of the radioelements worldwide are $33 \mathrm{~Bq} \mathrm{~kg}^{-1}$ for ${ }^{238} \mathrm{U}, 45 \mathrm{~Bq} \mathrm{~kg}{ }^{-1}$ for ${ }^{232} \mathrm{Th}$, and $412 \mathrm{~Bq} \mathrm{~kg}^{-1}$ for ${ }^{40} \mathrm{~K}$ (Mudd, 2008). The activity concentration values for the studied samples ranged from 12 to $148 \mathrm{~Bq} \mathrm{~kg}{ }^{-1}$ for ${ }^{238} \mathrm{U}$. About seventeen samples exceeded the worldwide average specific activity of ${ }^{238} \mathrm{U}$, and the samples with the highest value were Red Nefertiti (123.5 Bq kg$\left.{ }^{-1}\right)$, Gandolla (111.2 Bq kg$\left.{ }^{-1}\right)$, Light Rose $\left(86.45 \mathrm{~Bq} \mathrm{~kg}^{-1}\right)$, and Forsan $\left(74.1 \mathrm{~Bq} \mathrm{~kg}^{-1}\right)$. The P-factor of the investigated granitic samples was calculated (Table 1). It is clear that most values of the P-factor of the studied samples are more than one, referring to a possible loss of radon or radium, which can be indicated by a U/Ra average value up to 1.9 .

The U/Th ratio varied from 0.2 to 9.1 with an average of up to 1.4 and higher than the range commonly recorded for granites $(0.08-0.50)[25,26]$. This high ratio may reflect the enrichment of the studied granites with some accessory minerals, such as uranophane, autunite, monazite, zircon, and xenotime.

$\mathrm{Th} / \mathrm{U}$ ratio varied from 0.1 to 6.6 with 1.9 as the average content (Table 1). The crustal average content of $\mathrm{Th} / \mathrm{U}$ ratio was nearly 3 ; in these granitic rocks, the wide range of $\mathrm{Th} / \mathrm{U}$ ratio (0.1 and 6.6) suggests that the enrichment of uranium and thorium is related to hypogene fluids, which cause the enrichment of uranium and thorium by the same ratio. The disturbance of the $\mathrm{Th} / \mathrm{U}$ ratio (less than 3 ) indicates that the uranium enrichment is higher than that of thorium, due to the greater stability of thorium than uranium in the secondary environment. 
Table 1. Activity concentrations of ${ }^{238} \mathrm{U},{ }^{226} \mathrm{Ra},{ }^{232} \mathrm{Th}$ and ${ }^{40} \mathrm{~K}\left(\mathrm{~Bq} \mathrm{~kg}{ }^{-1}\right)$ and ratios for the studied granite samples.

\begin{tabular}{|c|c|c|c|c|c|c|c|}
\hline \multirow[b]{2}{*}{ Sample Code } & \multicolumn{4}{|c|}{ Radionuclide Activity (Bq kg ${ }^{-1}$ ) } & \multicolumn{3}{|c|}{ Activity Ratio } \\
\hline & $\mathrm{U}-238$ & Th-232 & Ra-226 & K-40 & $\mathbf{U} / \mathbf{R a}$ & U/Th & $\mathrm{Th} / \mathrm{U}$ \\
\hline BA1 & 49.40 & 36.54 & 11.10 & 1095.50 & 4.45 & 1.35 & 0.74 \\
\hline BA2 & 12.35 & 32.48 & 22.20 & 801.28 & 0.56 & 0.38 & 2.63 \\
\hline BA3 & 49.40 & 105.56 & 33.30 & 1430.41 & 1.48 & 0.47 & 2.14 \\
\hline BA4 & 24.70 & 44.66 & 22.20 & 870.14 & 1.11 & 0.55 & 1.81 \\
\hline BA5 & 24.70 & 56.84 & 11.10 & 848.23 & 2.23 & 0.43 & 2.30 \\
\hline GS1 & 12.35 & 60.90 & 22.20 & 1098.63 & 0.56 & 0.20 & 4.93 \\
\hline GS2 & 61.75 & 40.60 & 33.30 & 788.76 & 1.85 & 1.52 & 0.66 \\
\hline GS3 & 61.75 & 93.38 & 44.40 & 1064.20 & 1.39 & 0.66 & 1.51 \\
\hline LR1 & 37.05 & 97.44 & 55.50 & 1082.98 & 0.67 & 0.38 & 2.63 \\
\hline LR2 & 135.85 & 36.54 & 44.40 & 760.59 & 3.06 & 3.72 & 0.27 \\
\hline DR1 & 24.70 & 60.90 & 44.40 & 1045.42 & 0.56 & 0.41 & 2.47 \\
\hline DR2 & 61.75 & 89.32 & 44.40 & 1076.72 & 1.39 & 0.69 & 1.45 \\
\hline R1 & 24.70 & 48.72 & 22.20 & 1136.19 & 1.11 & 0.51 & 1.97 \\
\hline $\mathrm{R} 2$ & 24.70 & 56.84 & 33.30 & 1483.62 & 0.74 & 0.43 & 2.30 \\
\hline $\mathrm{R} 3$ & 49.40 & 48.72 & 22.20 & 1295.82 & 2.23 & 1.01 & 0.99 \\
\hline G1 & 74.10 & 48.72 & 33.30 & 1180.01 & 2.23 & 1.52 & 0.66 \\
\hline G2 & 148.20 & 93.38 & 88.80 & 1298.95 & 1.67 & 1.59 & 0.63 \\
\hline G3 & 111.15 & 64.96 & 44.40 & 1054.81 & 2.50 & 1.71 & 0.58 \\
\hline RA1 & 61.75 & 89.32 & 11.10 & 1139.32 & 5.56 & 0.69 & 1.45 \\
\hline RA2 & 12.35 & 60.90 & 11.10 & 1367.81 & 1.11 & 0.20 & 4.93 \\
\hline RA3 & 24.70 & 64.96 & 11.10 & 1305.21 & 2.23 & 0.38 & 2.63 \\
\hline WH1 & 18.53 & 89.32 & 22.20 & 1270.78 & 0.83 & 0.21 & 4.82 \\
\hline WH2 & 37.05 & 4.06 & 11.10 & 331.78 & 3.34 & 9.13 & 0.11 \\
\hline WH 3 & 12.35 & 8.12 & 4.44 & 209.71 & 2.78 & 1.52 & 0.66 \\
\hline YV1 & 12.35 & 81.20 & 33.30 & 1302.08 & 0.37 & 0.15 & 6.57 \\
\hline YV2 & 111.15 & 16.24 & 55.50 & 838.84 & 2.00 & 6.84 & 0.15 \\
\hline YV3 & 37.05 & 36.54 & 11.10 & 992.21 & 3.34 & 1.01 & 0.99 \\
\hline $\mathrm{RN}$ & 123.50 & 40.60 & 55.83 & 1245.74 & 2.21 & 3.04 & 0.33 \\
\hline $\mathrm{F}$ & 74.10 & 69.02 & 44.40 & 1198.79 & 1.67 & 1.07 & 0.93 \\
\hline Average & 52.2 & 57.8 & 31.2 & 1055.7 & 1.9 & 1.4 & 1.9 \\
\hline Min & 12.4 & 4.1 & 4.4 & 209.7 & 0.4 & 0.2 & 0.1 \\
\hline Max & 148.2 & 105.6 & 88.8 & 1483.6 & 5.6 & 9.1 & 6.6 \\
\hline
\end{tabular}

The activity concentration values of ${ }^{232} \mathrm{Th}$ ranged from 4 to $97 \mathrm{~Bq} \mathrm{~kg}^{-1}$. Comparing the activities of ${ }^{232} \mathrm{Th}$ of the studied samples with the average worldwide data [27], it appears that nineteen samples exceeded the value of $45 \mathrm{~Bq} \mathrm{~kg}^{-1}$, and the highest values are for Dark Rosa (75.11 Bq kg-1), Red Aswan (71.73 Bq kg ${ }^{-1}$ ), Gandolla and Forsan (69.02 Bq kg ${ }^{-1}$ ). As far as the specific activities of ${ }^{40} \mathrm{~K}$ are concerned, the Royal, Red Aswan, Red Nefertiti, Forsan, and Gandolla samples displayed the highest average values $(1305,1271,1246$, 1199 , and $1178 \mathrm{~Bq} \mathrm{~kg}{ }^{-1}$, respectively) and exceeded the average granite value for ${ }^{40} \mathrm{~K}$, which is $1104 \mathrm{~Bq} \mathrm{~kg}^{-1}$ [28]. The activity concentrations of ${ }^{226} \mathrm{Ra}$ for the studied granite 
samples ranged from 11 to $89 \mathrm{~Bq} \mathrm{~kg}^{-1}$ within an average value of $32 \mathrm{~Bq} \mathrm{~kg}^{-1}$. The activity concentration ranges of ${ }^{226} \mathrm{Ra},{ }^{232} \mathrm{Th}$, and ${ }^{40} \mathrm{~K}$ of the granite samples of this study were compared to those of different localities in the Eastern Desert of Egypt, with 137 granite samples from different countries all over the world, as shown in Table 2. The results showed that the activity concentrations of ${ }^{226} \mathrm{Ra},{ }^{232} \mathrm{Th}$, and ${ }^{40} \mathrm{~K}$ in the studied samples are lower than most values of granitic rocks in the Eastern Desert and the international samples.

Table 2. Comparison of activity concentrations of the natural radionuclides $\left({ }^{226} \mathrm{Ra},{ }^{232} \mathrm{Th}\right.$ and $\left.{ }^{40} \mathrm{~K}\right)\left(\mathrm{Bq} \mathrm{kg}{ }^{-1}\right)$ in granite samples of the present study with those obtained in other published data.

\begin{tabular}{|c|c|c|c|c|c|c|c|}
\hline Country & & Region & No. of Samples & ${ }^{226} \mathrm{Ra}$ & ${ }^{232} \mathrm{Th}$ & ${ }^{40} \mathrm{~K}$ & Reference \\
\hline \multirow{10}{*}{ 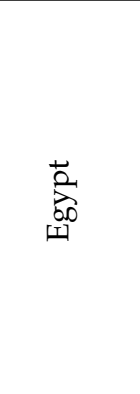 } & \multirow{10}{*}{ 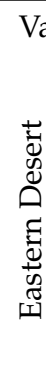 } & f Aswan Granite & 29 & $11-89$ & $4-97$ & $210-1484$ & Present study \\
\hline & & G. Qash Amir & - & 6.4-65.3 ppm & $11.4-43.8 \mathrm{ppm}$ & $3.2-7.5 \mathrm{ppm}$ & [29] \\
\hline & & G. El Sela & - & 103-2047 & $12.4-101.2$ & 831.6-1394.6 & [30] \\
\hline & & W. Allaqi & 11 & 9-111 & 8-75 & 119-790 & [31] \\
\hline & & Abu Ziran & 6 & $19-34$ & $11-15$ & $216-274$ & [31] \\
\hline & & Gattar (GII) & 50 & $165-27,851$ & $71-274$ & $1048-1230$ & [32] \\
\hline & & Gattar (GV) & 15 & $174-50,378$ & 51-902 & 640-1841 & [33] \\
\hline & & El-Missikat & 9 & $12.4-534.4$ & $56.6-169.8$ & 398-1113 & [9] \\
\hline & & Wadi El-Gemal & - & 25-59 & 28-759 & $970-1280$ & [34] \\
\hline & & Ras Baroud & - & $11.5-172.8$ & $18.4-103.4$ & $87.9-454.7$ & [35] \\
\hline \multicolumn{3}{|c|}{ Different countries all over the world } & 167 & $0.2-160$ & $<4-253$ & $<36-2355$ & [36] \\
\hline
\end{tabular}

Figure 5 shows the correlation between ${ }^{238} \mathrm{U}$ and ${ }^{232} \mathrm{Th}$ radionuclides in all measured samples: there is a positive correlation between ${ }^{238} \mathrm{U}$ and ${ }^{232} \mathrm{Th}$ with fitting the equation ${ }^{232} \mathrm{Th}=0.01877 \times{ }^{238} \mathrm{U}+56.84$ and standard error \pm 0.13 . The band with the orange color around the fit line is the confidence band, which depicts the upper and lower confidence bounds for all points on a fitted line within the range of data; for example, the model indicates with 95 confidence that in a sample, if ${ }^{238} \mathrm{U}=80$, this indicates that in the same sample, there is a proximity of 45 to $75^{232} \mathrm{Th}$, which are the $\mathrm{y}$-values of the lower and upper confidence bands at ${ }^{238} \mathrm{U}=15$. The same applies to the prediction band. The results include a 4-panel residuals plot. Residuals are also analyzed for normality using the AndersonDarling test. Looking at the Fitted $\mathrm{Y}(\mathrm{Bq} / \mathrm{kg})$ figure of the residuals, we can see how they are constant from left to right, which is called the constant variance of the residuals; also, in the percentiles figure, we can see how they are distributed around the fitted line, which proves the initial assumption. The residual count figure shows that most of the residuals are between 0 and 0.5 , while the last figure explains the relationship between the residuals against each independent variable; as we can see, there is no pattern clearly related to one of the independents.

The sampling site-specific variations of ${ }^{238} \mathrm{U},{ }^{226} \mathrm{Ra},{ }^{232} \mathrm{Th}$, and ${ }^{40} \mathrm{~K}$ radioactivity concentrations $\left(\mathrm{Bq} \mathrm{kg}^{-1}\right)$ with minimum, mean and maximum values for the studied samples shown in Figure 6. G2 sample has the highest values of ${ }^{238} \mathrm{U}\left(148.20 \mathrm{~Bq} \mathrm{~kg}^{-1}\right)$ and ${ }^{226} \mathrm{Ra}$ $\left(88.80 \mathrm{~Bq} \mathrm{~kg}^{-1}\right)$, while the BA3 and R2 samples have the highest values of ${ }^{232} \mathrm{Th}$ (105.56, $\mathrm{Bq} / \mathrm{kg})$ and ${ }^{40} \mathrm{~K}\left(1483.62 \mathrm{~Bq} \mathrm{~kg}^{-1}\right)$, respectively.

In Figure 7, the histograms are presented for the data of the activity concentration results for ${ }^{238} \mathrm{U},{ }^{232} \mathrm{Th},{ }^{226} \mathrm{Ra}$, and ${ }^{40} \mathrm{~K}$ in twenty-nine different samples of Aswan granites. The data present a strong normal distribution from this figure, and all the values of activity concentrations are nearly within the computed mean value for each natural radionuclide. The statistical distribution of the results, the activity concentration results for ${ }^{238} \mathrm{U},{ }^{232} \mathrm{Th}$, ${ }^{226} \mathrm{Ra}$, and ${ }^{40} \mathrm{~K}$ in the studied points of Aswan granites, are presented in Figure 8 using boxplots. The ${ }^{40} \mathrm{~K}$ has the highest values of the range, median, mean, and outliers of Aswan granites. 


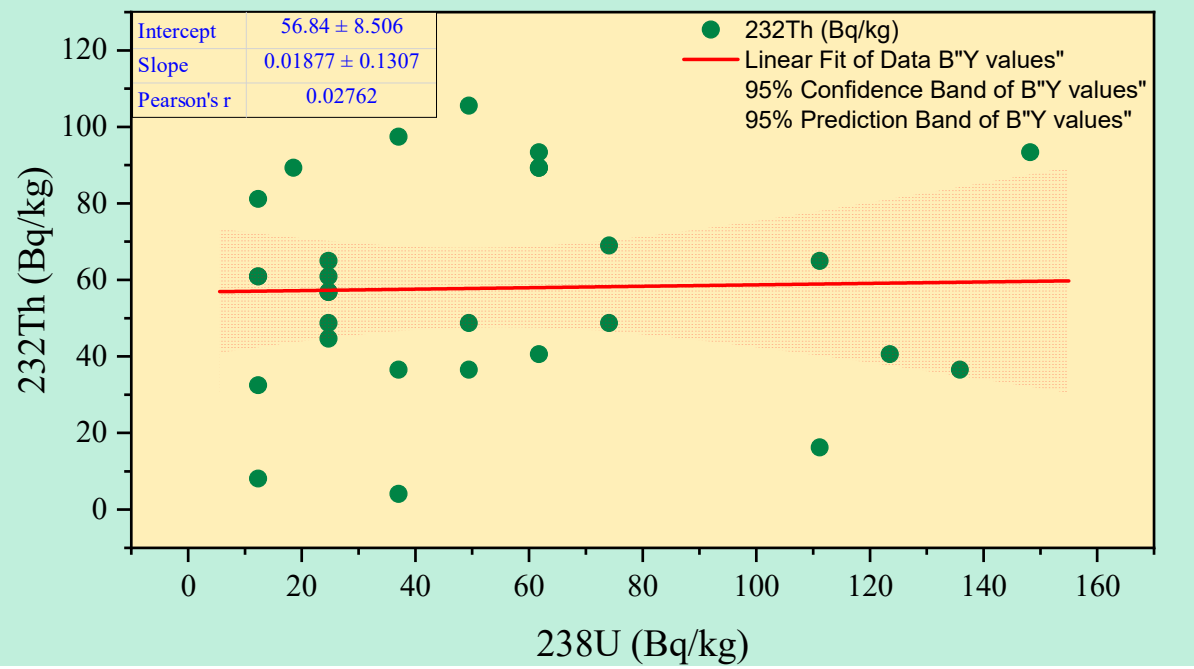

\section{Residuals}
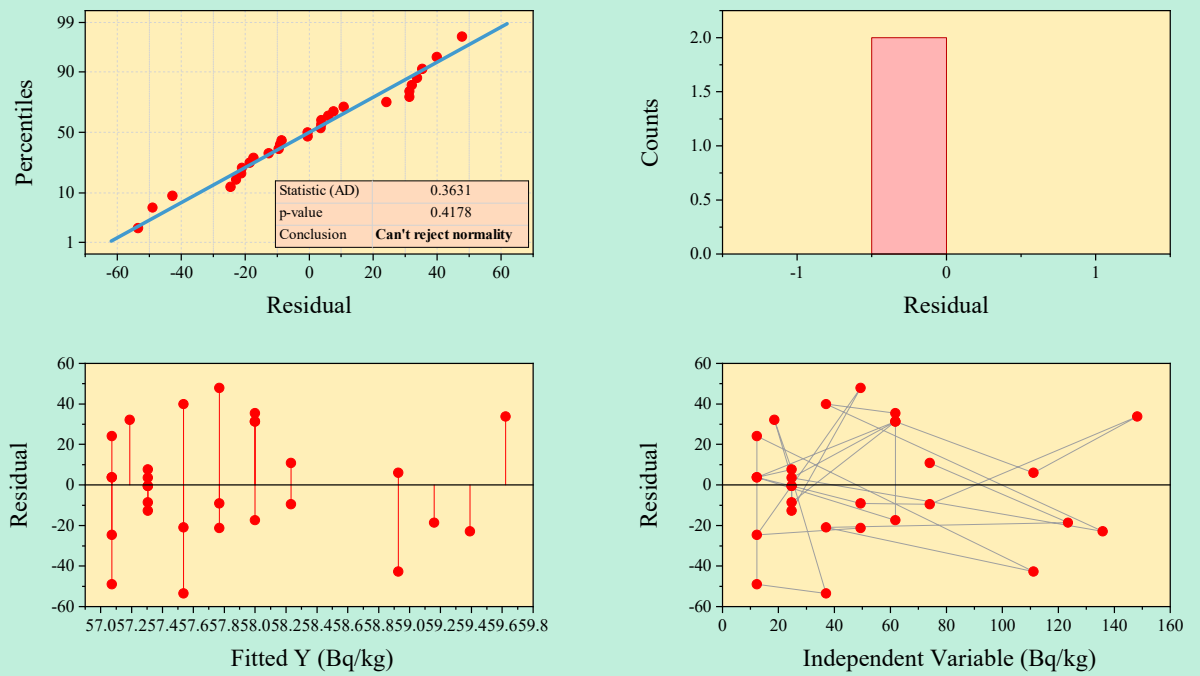

Figure 5. Linear regression LR with residuals analysis of ${ }^{232} \mathrm{Th}$ to ${ }^{238} \mathrm{U}$ of granitic rocks samples.

\subsection{Radiological Hazards Indices}

In order to assess the radiological hazard for populations exposed to the radiations emitted by the granite samples, several indices were calculated based on the concentrations obtained in this work for ${ }^{40} \mathrm{~K}\left(\mathrm{C}_{\mathrm{K}}\right),{ }^{232} \mathrm{Th}\left(\mathrm{C}_{\mathrm{Th}}\right)$ and ${ }^{226} \mathrm{Ra}\left(\mathrm{C}_{\mathrm{Ra}}\right)$ [2,37-39].

The external hazard index $\left(\mathrm{H}_{\mathrm{ex}}\right)$ commonly used to evaluate radiation dose rate due to external exposure to gamma radiation from natural radionuclides in soil/rock samples is presented in the next equation. The calculated average external hazard index was found to be less than unity for the radiation hazard to be insignificant.

$$
\mathrm{H}_{\mathrm{ex}}=\frac{\mathrm{C}_{\mathrm{k}}}{4810}+\frac{\mathrm{C}_{\mathrm{Th}}}{259}+\frac{\mathrm{C}_{\mathrm{Ra}}}{370} \leq 1
$$




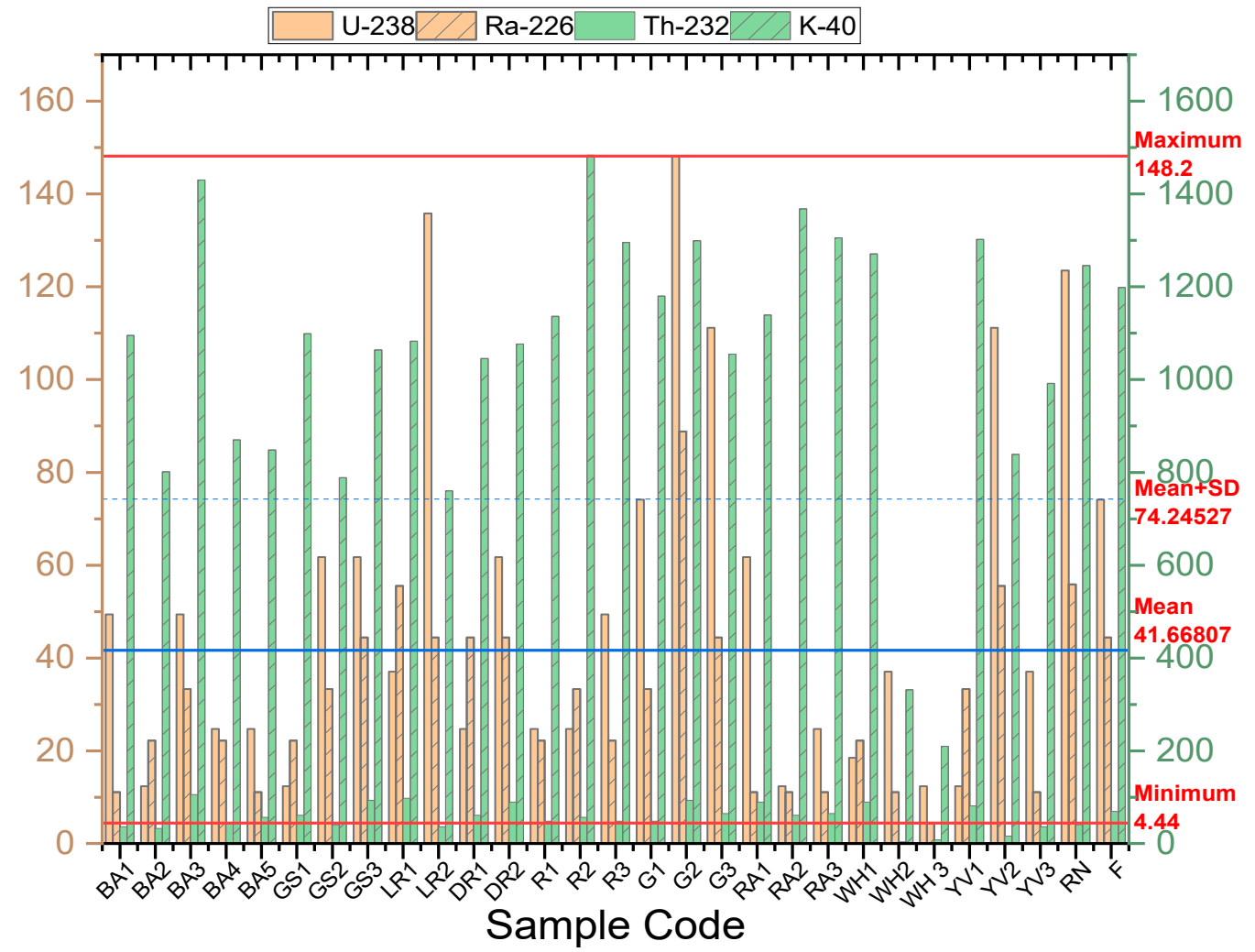

Figure 6. Activity concentrations $(\mathrm{Bq} \mathrm{kg}-1)$ of the radioelements $\left({ }^{238} \mathrm{U},{ }^{226} \mathrm{Ra},{ }^{232} \mathrm{Th}\right.$ and $\left.{ }^{40} \mathrm{~K}\right)$ found in granitic rock samples (right scale is for ${ }^{40} \mathrm{~K}$ ).
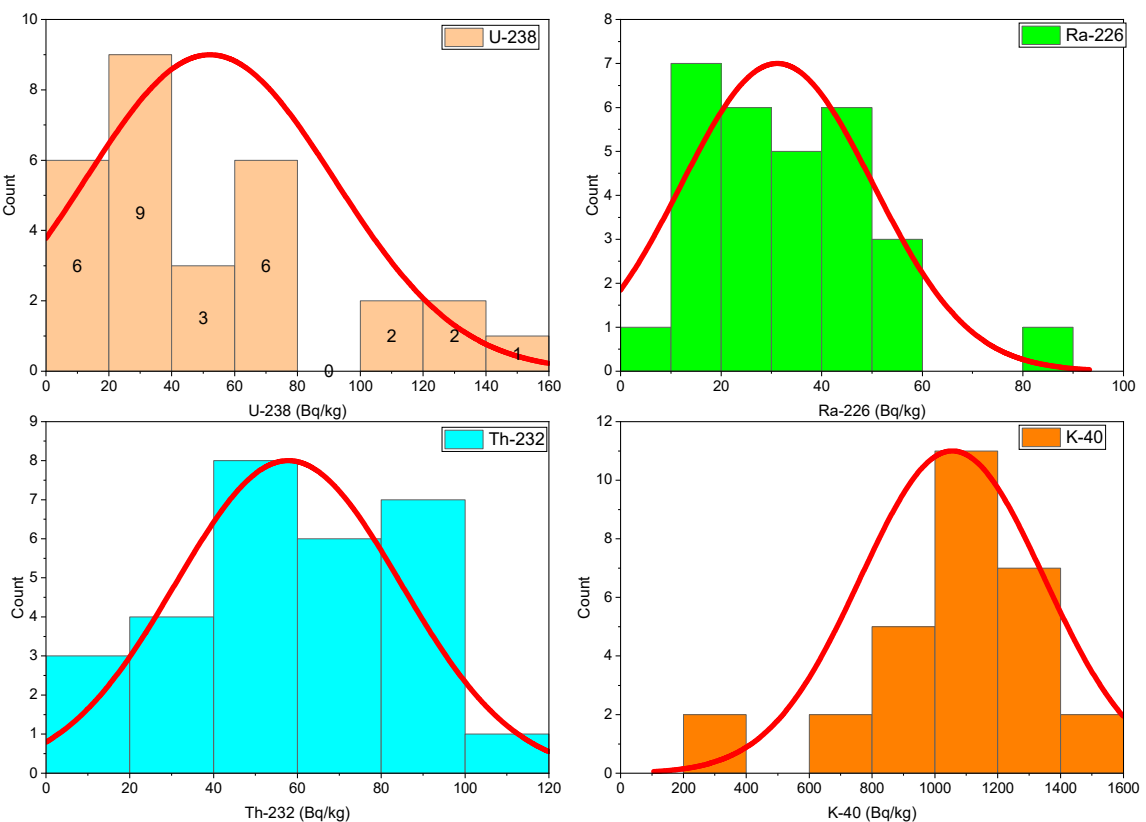

Figure 7. Frequency distribution of the ${ }^{238} \mathrm{U},{ }^{226} \mathrm{Ra},{ }^{232} \mathrm{Th}$ and ${ }^{40} \mathrm{~K}$ radionuclides in granitic rocks samples. 


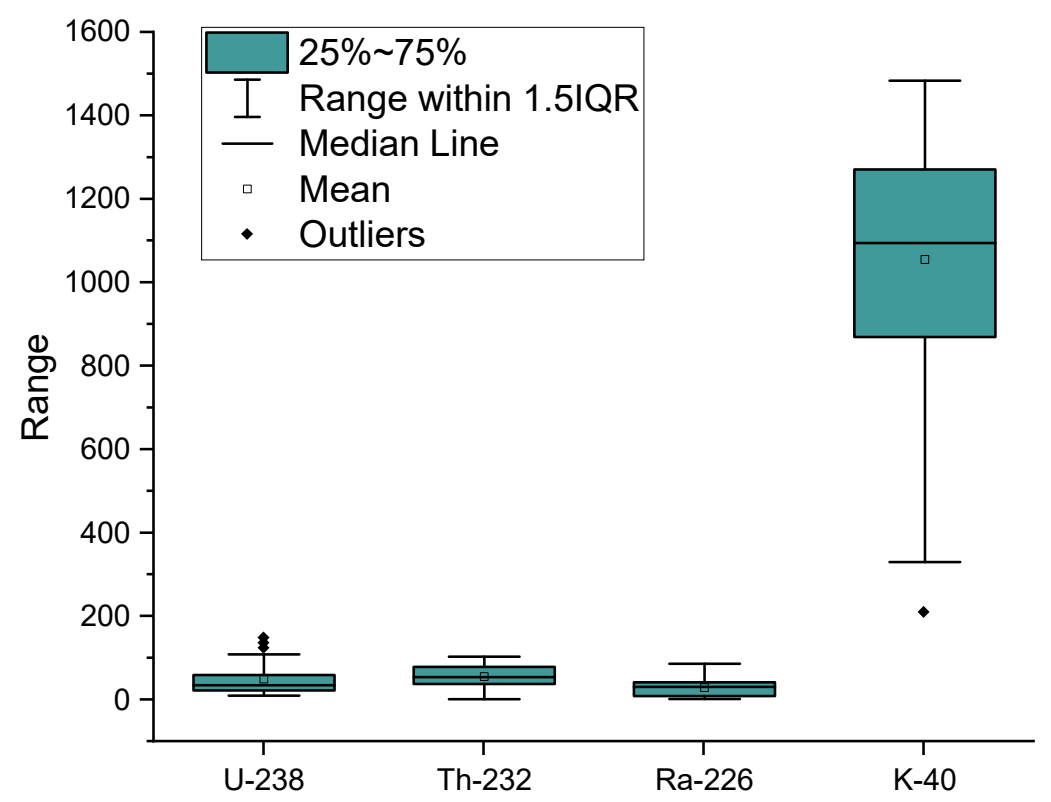

Figure 8. Range, mean, median line and outliers for ${ }^{238} \mathrm{U},{ }^{226} \mathrm{Ra},{ }^{232} \mathrm{Th}$, and ${ }^{40} \mathrm{~K}$ activities in the measured samples in interested area.

The internal exposure to ${ }^{222} \mathrm{Rn}$ and its radioactive progeny is controlled by the internal hazard index $\left(\mathrm{H}_{\text {in }}\right)$. The internal hazard index $\left(\mathrm{H}_{\text {in }}\right)$ is a parameter for estimating the negative effect of radioactive materials on the lungs and other respiratory organs. For example, the risk of internal exposure due to the natural radionuclides ${ }^{40} \mathrm{~K},{ }^{226} \mathrm{Ra}$, and ${ }^{232} \mathrm{Th}$ can be assessed from the value of the $\mathrm{H}_{\text {in }}$ equation:

$$
\mathrm{H}_{\mathrm{in}}=\frac{\mathrm{C}_{\mathrm{k}}}{4810}+\frac{\mathrm{C}_{\mathrm{Th}}}{259}+\frac{\mathrm{C}_{\mathrm{Ra}}}{185}
$$

The European Commission (1999) [37] proposed the gamma-ray index (I $\gamma$ ), which is strongly related to the annual effective dose. The gamma-ray index is calculated considering a standard room model with dimensions of $4 \mathrm{~m} \times 5 \mathrm{~m} \times 2.8 \mathrm{~m}$ and $20 \mathrm{~cm}$-thick walls. The formula calculates this index factor associated to the external exposure:

$$
\mathrm{I} \gamma=\frac{\mathrm{C}_{\mathrm{Ra}}}{300}+\frac{\mathrm{C}_{\mathrm{Th}}}{200}+\frac{\mathrm{C}_{\mathrm{k}}}{3000}
$$

The excess alpha radiation due to radon inhalation originating from building materials is estimated using the relation below:

$$
\mathrm{I} \alpha=\frac{\mathrm{C}_{\mathrm{Ra}}}{200} \leq 1
$$

I $\alpha$ should be lower than the maximum permissible value of $I \alpha=1$, which corresponds to $200 \mathrm{~Bq} \mathrm{~kg}{ }^{-1}$. For alpha radiation is considered that a building material with Ra concentration lower than $200 \mathrm{~Bq} \mathrm{~kg}^{-1}$ could not cause an indoor radon concentration higher than $200 \mathrm{~Bq} \mathrm{~m}^{-3}$.

The internal hazard index $\left(\mathrm{H}_{\text {in }}\right)$ for the studied Aswan granites ranged from 0.07 to 0.9. These values are within the limit of safety value of 1 as recommended by the European Commission [37], except for sample No. 14 for the Gandolla 2 sample, which had $\mathrm{H}_{\text {in }}$ of 1.11, which is higher than the safety limit. Furthermore, the external hazard index $\left(\mathrm{H}_{\mathrm{ex}}\right)$ must also be less than the unity to maintain a negligible radiation hazard. Therefore, the external hazard index estimated for the studied Aswan granite samples was less than the safety limit as given in Figure 9. 

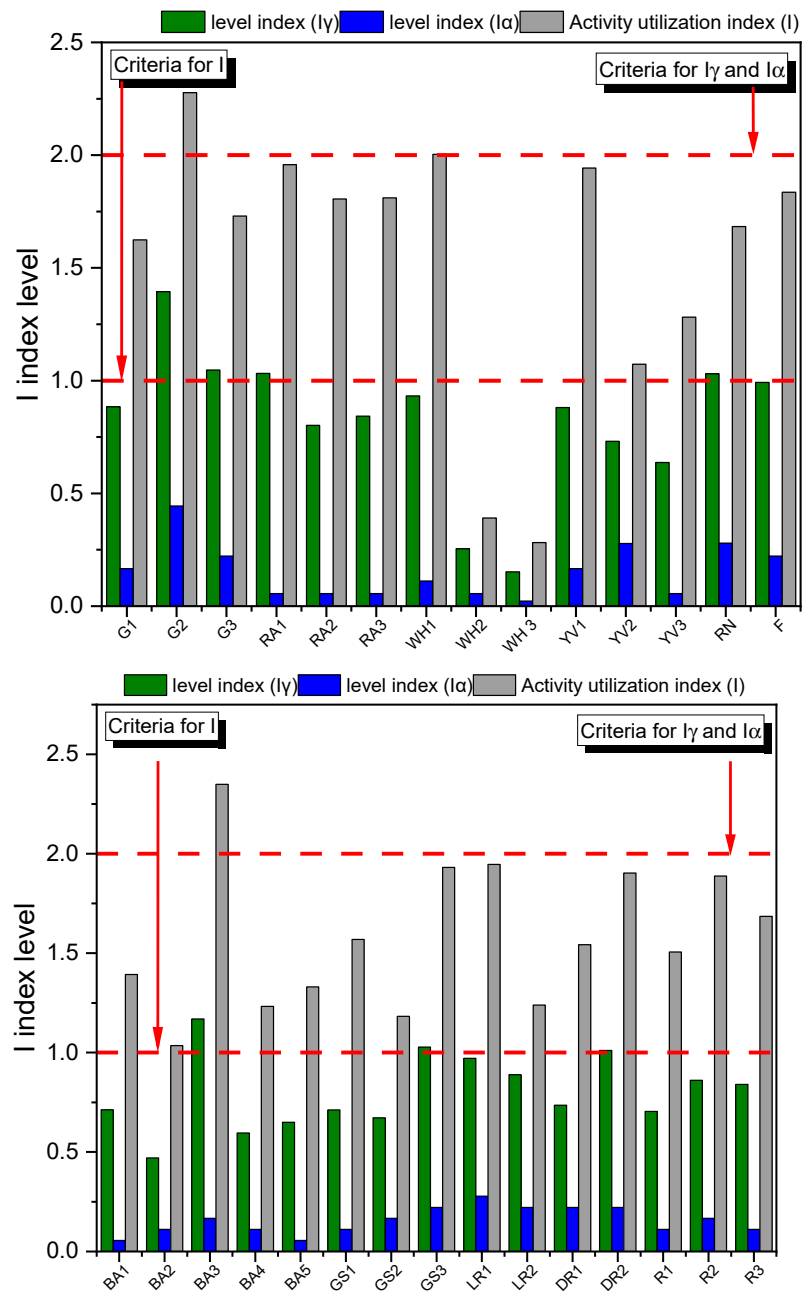

Figure 9. External ( $\gamma$-radioactivity) and internal ( $\alpha$-radioactivity) level indices and activity utilization index.

The gamma-ray index is correlated with the annual dose rate due to gamma radiation (external exposure). Materials having $\mathrm{I} \gamma<2$ would increase the yearly effective dose by $0.3 \mathrm{mSv}$, while for $2<\mathrm{I} \gamma<6$, the gamma-ray index corresponds to an increase in effective dose by $1 \mathrm{mSv}$ y-1. Building materials used superficially rather than in bulk amounts (tiles, boards, etc.) should be exempted from all restrictions concerning radioactivity, if the excess of gamma radiation originating from them increases the annual effective dose of a member of the public by $0.3 \mathrm{mSv}$ at the most. On the other hand, dose rates higher than $1 \mathrm{mSv} \mathrm{y}^{-1}$ are allowed only in exceptional cases, where materials are locally used. Finally, samples with $\mathrm{I} \gamma>6$ cannot be recommended for use in buildings [37].

\section{Conclusions}

Granitic rock is considered one of the most important economic materials used for building materials, ornamental stones, and other purposes. Aswan granites consist of alkali-feldspars, plagioclase, quartz, biotite, and hornblendein, in addition to accessory minerals, such as zircon, allanite, epidote, titanite, and iron oxides. Eleven different kinds represented by twenty-nine samples of Aswan granites, considered the most popular ones, were measured for their natural radioactivity to assess the radioactive concentrations when used as building materials.

The activities of ${ }^{238} \mathrm{U},{ }^{226} \mathrm{Ra},{ }^{232} \mathrm{Th}$, and ${ }^{40} \mathrm{~K}$ for most of the studied granites exceeded the average level of these radionuclides, according to the average values of the radioele- 
ments worldwide. The statistical distribution of ${ }^{40} \mathrm{~K}$ of the Aswan granites showed the highest values of the range, median, mean, and outliers of Aswan granites.

According to the results obtained for the external ( $\gamma$-radioactivity) and internal ( $\alpha$ radioactivity) level indices and the activity utilization index, the majority of the investigated granite samples are suitable for use as building materials, posing no hazard to the population.

Author Contributions: Conceptualization, N.M.M., H.A.A. and H.M.H.Z.; data curation, H.M.H.Z., S.A.M.I. and A.E.; formal analysis, N.M.M., M.M.F. and H.M.H.Z.; funding acquisition, A.E.; investigation, A.M.E.-T., H.A.A., H.M.H.Z., S.A.M.I. and A.E.; methodology, N.M.M. and A.M.E.-T.; project administration, H.M.H.Z. and A.E.; resources, N.M.M., A.M.E.-T. and M.M.F.; software, M.M.F., H.M.H.Z. and S.A.M.I.; supervision, N.M.M., A.M.E.-T., S.A.M.I. and A.E.; validation, M.M.F., H.A.A., H.M.H.Z., S.A.M.I. and A.E.; visualization, H.A.A. and H.M.H.Z.; writing-original draft, N.M.M., H.A.A. and H.M.H.Z.; writing-review and editing, H.A.A., H.M.H.Z., S.A.M.I. and A.E. All authors have read and agreed to the published version of the manuscript.

Funding: The APC is funded by "Dunarea de Jos" University of Galati, Romania.

Institutional Review Board Statement: Not applicable.

Informed Consent Statement: Not applicable.

Acknowledgments: The work of the corresponding author A.E. was carried out at INPOLDE research center of Dunarea de Jos University of Galati, Romania, in the frame of the project BSB27-MONITOX (2018-2021), Joint Operational Programme Black Sea Basin 2014-2020. The researchers (H.A.A. and H.M.H.Z.) are funded by a partial scholarship from the ministry of higher education of Egypt.

Conflicts of Interest: The authors declare no conflict of interest.

\section{References}

1. Sonkawade, R.; Kant, K.; Muralithar, S.; Kumar, R.; Ramola, R.C. Natural radioactivity in common building construction and radiation shielding materials. Atmos. Environ. 2008, 42, 2254-2259. [CrossRef]

2. Zakaly, H.M.; Uosif, M.A.; Madkour, H.; Tammam, M.; Issa, S.; Elsaman, R.; El-Taher, A. Assessment of natural radionuclides and heavy metal concentrations in marine sediments in view of tourism activities in Hurghada city, northern Red Sea, Egypt. J. Phys. Sci. 2019, 30, 21-47. [CrossRef]

3. UNSCEAR. Sources and Effects of Ionizing Radiation; Annex, B., Ed.; Exposures from Natural Radiation Sources; UNSCEAR 2000 REPORT; United Nations: New York, NY, USA, 2000; Volume I.

4. Tsirambides, A. The Greek Marbles and Other Decorative Stones; University Studio Press: Thessaloniki, Greece, 1996.

5. El-Gamal, H.; Sidique, E.; El-Haddad, M. Spatial distributions and risk assessment of the natural radionuclides in the granitic rocks from the Eastern Desert, Egypt. Minerals 2019, 9, 386. [CrossRef]

6. Ene, A.; Pascu, E.; Stavarache, M. Granite slabs between radiation and design. In Proceedings of the Abstract Book International Scientific Conference "Environmental Challenges in the Black Sea Basin: Impact on Human Health", Galati, Romania, 23-26 September 2020; Ene, A., Teodorof, L., Eds.; Casa Cartii de Stiinta: Cluj Napoca, Romania, 2020; pp. 44-45.

7. Rashwan, M.; Darwish, M. Structural Dynamic Characteristics of an Ancient Egyptian Obelisk. In Facing the Challenges in Structural Engineering. GeoMEast 2017. Sustainable Civil Infrastructures; Rodrigues, H., Elnashai, A., Calvi, G., Eds.; Springer: Cham, Switzerland, 2018. [CrossRef]

8. Awad, H.A.; Zakaly, H.M.H.; Nastavkin, A.V.; El-Taher, A. Radioactive content in the investigated granites by geochemical analyses and radiophysical methods around Um Taghir, Central Eastern Desert, Egypt. J. Phys. Conf. Ser. 2020, 1582, 012007. [CrossRef]

9. Awad, H.A.; Zakaly, H.M.; Nastavkin, A.V.; El Tohamy, A.M.; El-Taher, A. Radioactive mineralizations on granitic rocks and silica veins on shear zone of El-Missikat area, Central Eastern Desert, Egypt. Appl. Radiat. Isot. 2021, 168, 109493. [CrossRef] [PubMed]

10. Malek, J.; Nicholson, P.T.; Shaw, I. Stones. In Ancient Egyptian Materials and Technology; Nicholson, P.T., Shaw, I., Eds.; University of Cambridge Press: Cambridge, UK, 2000; pp. 5-77.

11. Whicker, F.W.; Eisenbud, M.; Gesell, T. Environmental radioactivity from natural, industrial, and military sources. Radiat. Res. 1997, 148, 402. [CrossRef]

12. Gindy, A.R.; Tamish, M.M. Petrogenetic revision of the basement rocks in the environs of Aswan, southern Egypt. Egypt J. Geol. 1998, 42, 1-14.

13. Noweir, A.M.; Abu El Ela, A.M.; Sewifi, B.M. New contributions to the geology, geochemistry and tectonic setting of the Aswan granites. Qatar Univ. Sci. Bull. 1990, 10, 395-419.

14. Ragab, A.I.; Meneisy, M.Y.; Taher, R.M. Contributions to the petrogenesis and age of Aswan granitic rocks, Egypt. Neu. Jahrb Miner. Abh. 1978, 133, 71-87.

15. Ammar, S.E. Acidic and intermediate rocks suite at Aswan Cataract; Petrogenetic studies, Egypt. J. Geol. 2003, 47, 1199-1213. 
16. Assran, H.M. Petrology and radioactivity of the famous Aswan monumental red granites new occurrence, Gebel Um Shaghir area, South Western Desert, Egypt. Arab. J. Geosci. 2015, 8, 7719-7729. [CrossRef]

17. Kusky, T.M.; Abdelsalam, M.; Tucker, R.D.; Stern, R.J. Evolution of the East African and related orogens, and the assembly of Gondwana. Precambrian Res. 2003, 123, 81-85. [CrossRef]

18. Greiling, R.O.; Rashwan, A.A.; El Ramly, M.F.; El Din, G.M.K. Towards a comprehensive structural synthesis of the (proterozoic) arabian-nubian shield in E. Egypt. In Geoscientific Research in Northeast Africa; Springer: Berlin/Heidelberg, Germany, 2017; pp. 15-19. [CrossRef]

19. Papaefthymiou, H.; Papatheodorou, G.; Moustakli, A.; Christodoulou, D.; Geraga, M. Natural radionuclides and 137Cs distributions and their relationship with sedimentological processes in Patras Harbour, Greece. J. Environ. Radioact. 2007, 94, 55-74. [CrossRef]

20. Ene, A.; Pantelica, A. Characterization of metallurgical slags using low-level gamma-ray spectrometry and neutron activation analysis. Rom. J. Phys. 2011, 56, 1011-1018.

21. Malczewski, D.; Teper, L.; Dorda, J. Assessment of natural and anthropogenic radioactivity levels in rocks and soils in the environs of Swieradow Zdroj in Sudetes, Poland, by in situ gamma-ray spectrometry. J. Environ. Radioact. 2004, 73, 233-245. [CrossRef]

22. Said, A.F.; Salam, A.M.; Hassan, S.F.; Mohamed, W.S. Assessment of the Environmental Radioactivity Impacts and Health Hazards Indices at Wadi Sahu Area, Sinai, Egypt. In Proceedings of the Tenth Radiation Physics \& Protection Conference, Cairo, Egypt, 27-30 November 2010; pp. 145-159.

23. IAEA. Guidelines for Radioelement Mapping Using Gamma Ray Spectrometry Data; IAEA-TECDOC-1363; IAEA: Vienna, Austria, 2003; pp. 6-7.

24. IAEA. Evaluating the Reliability of Predictions Made Using Environmental Transfer Models; Safety Series: No. 100; International Atomic Energy Agency: Vienna, Austria, 1989.

25. Rogers, J.J.W.; Adams, J.S.S. Uranium. In Handbook of Geochemistry; Wedepohl, K.H., Ed.; Springer: New York, NY, USA, 1969; pp. 92 B1-92 C10.

26. Stuckless, J.S.; Bunker, C.M.; Bush, C.A.; Doering, W.P.; Scott, J.H. Geochemical and petrological studies of a uraniferous granite from the Granite Mountains, Wyoming. J. Res. US Geol. Surv. 1977, 5, 61-81.

27. Mudd, G.M. Radon releases from Australian uranium mining and milling projects: Assessing the UNSCEAR approach. J. Environ. Radioact. 2008, 99, 288-315. [CrossRef]

28. United Nations Scientific Committee on the Effects of Atomic Radiation. Sources and Effects of Ionzing Radiation; United Nations Scientific Committee on the Effects of Atomic Radiation: 1994 Report to the General Assembly, with Scientific Annexes, Nature; United Nations: New York, NY, USA, 1994.

29. Ghoneim, M.M.; Gawad, A.E.A.; Awad, H.A.; Hesham, M.H.Z.; Mira, H.I.; El-Taher, A. Distribution patterns of natural radioactivity and rare earth elements in intrusive rocks (El Sela area, Eastern Desert, Egypt). Int. J. Environ. Anal. Chem. 2021, 1-14. [CrossRef]

30. Nagar, M.S.; Shahin, H.A.; Bahige, M. Column Percolation Leaching of Uranium from El-Sela Area, South Eastern Desert, Egypt. Res. Rev. J. Chem. 2016, 5, 32-41.

31. Issa, S.A.M.; Uosif, M.A.M.; El-Salam, L.M.A. Natural radionuclide concentrations in granite rocks in Aswan and Central-Southern Eastern Desert, Egypt and their radiological implications. Radiat. Prot. Dosim. 2012, 150, 488-495. [CrossRef]

32. El-Shershaby, A. Study of radioactivity levels in granite of Gable Gattar II in the north eastern desert of Egypt. Appl. Radiat. Isot. 2002, 57, 131-135. [CrossRef]

33. Walley El-Dine, N. Study of natural radioactivity and the state of radioactive disequilibrium in U-series for rock samples, North Eastern Desert, Egypt. Appl. Radiat. Isot. 2008, 66, 80-85. [CrossRef] [PubMed]

34. Ahmed, N.K.; Abbady, A.; El Arabi, A.M.; Michel, R.; El-Kamel, A.H.; Abbady, A.G.E. Comparative study of the natural radioactivity of some selected rocks from Egypt and Germany. Indian J. Pure Appl. Phys. 2006, 44, 209-215.

35. Uosif, M.A.M.; Abdel-Salam, L.M. An assessment of the external radiological impact in granites and pegmatite in central eastern desert in Egypt with elevated natural radioactivity. Radiat. Prot. Dosim. 2011, 147, 467-473. [CrossRef] [PubMed]

36. Chen, C.-J.; Lin, Y.-M. Assessment of building materials for compliance with regulations of ROC. Environ. Int. 1997, 22 (Suppl. 1), 221-226. [CrossRef]

37. European Commission. Radiation Protection 112: Radiological Protection Principles Concerning the Natural Radioactivity of Building Materials Directorate-General Environment, Nuclear Safety and Civil Protection; Office for Official Publications of the European Communities: Luxembourg, 1999.

38. Nada, A. Evaluation of natural radionuclides at Um-Greifat area, Eastern Desert of Egypt. Appl. Radiat. Isot. 2003, 58, 275-280. [CrossRef]

39. International Commission on Radiological Protection (ICRP). The 1990-91 Recommendations of the International Commission on Radiological Protection; Publication 60, Ann. ICRP 21; ICRP: Stockholm, Sweden, 1992. 